\title{
Anthós
}

2014

\section{Américo Castro and His Idea of Saint James: The Historiographical Legacy}

Daniel Blanchard

Portland State University

Follow this and additional works at: https://pdxscholar.library.pdx.edu/anthos

Part of the Political History Commons

Let us know how access to this document benefits you.

\section{Recommended Citation}

Blanchard, Daniel (2014) "Américo Castro and His Idea of Saint James: The Historiographical Legacy," Anthós: Vol. 6: Iss. 1, Article 4.

https://doi.org/10.15760/anthos.2014.51

This open access Article is distributed under the terms of the Creative Commons Attribution-NonCommercialShareAlike 4.0 International License (CC BY-NC-SA 4.0). All documents in PDXScholar should meet accessibility standards. If we can make this document more accessible to you, contact our team. 


\section{Américo Castro and His Idea of Saint James: The Historiographical Legacy}

Daniel W. Blanchard

This essay aims in essence to echo what the late great Hispanist Albert A. Sicroff suggested in an article published over forty years ago, in the winter preceding Américo Castro's death. Sicroff said of Castro, "Despite his critics, he has made formidable contributions toward understanding what went on within that Spanish morada vital to produce some of the most magnificent expressions of human existence the world has known." ${ }^{i}$ Indeed, Castro faced many critics as he flourished as one of the twentieth century's most prestigious scholars of Spanish history and culture. Yet his critics, as Sicroff has explained, often demonstrated a misunderstanding of the very concepts they rejected, resorting to oversimplified versions of Castro's thought, "full of distortions and omissions."ii While Sicroff addressed a body of criticism centered in the nineteen-fifties and sixties, it is unfortunate to find that historians of the past half-century have changed very little in their approach to Castro's scholarship.

The polemical debate surrounding Spanish national identity that had a significant impact on Castro, and to which some critics believe he himself contributed in his most well-known works, has largely faded into the abyss of Franco-era Spain. While the debate lingered for some time in the late-seventies and eighties, historiographers have explained it lost its raison d'etre shortly after Franco's death in 1975, and thereafter Spain's entrance into the European Community (now European Union) in 1986. ${ }^{\text {ii }}$ The tendency of the historiography of the last half-century has been to filter Castro's ideas through this polemic on Spanish national character without paying serious attention to the 
nuances of his historical analyses. To designate Castro simply as a polemicist oriented against Franco's Spain, however, is to ignore the value of the theoretical elements composing his broader conception of Spanish history. Moreover it is hypocritical to discredit the value of Castro's contributions to the study of Spain, due to their supposed rhetorical distortions of historicity, when many present-day historians operate within similar, if not exactly the same, theoretical frameworks.

Castro introduced his idea of Saint James in his 1948 text España en su historia. He revised the text three times, producing new editions in 1954, renamed La realidad histórica de España and translated as The Structure of Spanish History by Edmund L. King with Castro's close supervision, and again revised in 1962. These reworked editions integrated new chapters and further defenses of Castro's historical philosophy into the narrative of the original text. While Castro made these additions, his conception of Saint James remained the same. José Rubia Barcia noted, "For Don Américo, Santiago is not of Galicia, but of Spain, and although he deletes, adds and revises some chapters in the successive editions of España en su historia, he always includes, with slight modifications, the chapters on Santiago as the central and main key for the understanding of Spanish history." ${ }^{\text {iv }}$ Furthermore Castro published a defense of his idea of the Saint in his 1958 text Santiago de España, in which he made clear that the Saint was "integrated into the vital entity of Spain."v This essay elucidates what exactly Castro means by this claim. Rather than apprehending Castro's idea of Saint James in a context external to his own philosophy of history, however, the present essay clarifies how the Saint functions within it. To Castro the Saint is not a happening, isolated in the context of its historical place. It is integrated into the very living experience of Spanishness. From this exercise it can be gleaned that Castro's idea of Saint James is qualified within his own philosophy of history, that the Saint functions accordingly to, and is a product of, the historical process of Spain's self-fashioning. 
Castro informs his reader early in The Structure of Spanish History that his unique method of viewing history cannot be grasped solely by logical reason. ${ }^{\text {vi }}$ Therefore Saint James in Castro's view is an historical phenomenon that may make little sense to the reader without first considering the theoretical framework within which the idea operates. The first and most fundamental to grasp is the idea that Spain is constituted of a vital essence, made up by the collective belief of a people, and reflected in its cultural productions. "Spain was a faith, a belief," says Castro, "fed by life and by death, by heaven and by earth."vii Castro gives context to such an abstraction by examining the works of twentieth-century philosopher Miguel de Unamuno, who wrote of the Spanish people's vital connection between the empirical and spiritual conditions of life. Unamuno described Spain as a land under heaven, full of heaven - a body - and from the body, the idea that Spain has a soul. ${ }^{\text {viii }}$ Castro finds throbbing in Unamuno's lyricism "ten centuries of yearning existence."ix Unamuno expresses, for Castro, an existential crisis that is intrinsic to Spain, what Castro calls its "primordial phenomenon." ${ }^{x}$ Spain has faced an initial and constant problem since the Middle Ages, a problem of "insecurity and anguish concerning its own existence, its uncertainty, its living in a state of alarm caused by doubt."xi Effectively Castro's philosophy of history is to take up this existential crisis in the context of historical inquiry. In doing so he aims not only to preserve, but also accurately to represent the vital essence of Spanishness.

Castro uses the basis of existential philosophy to coin his own terms, composing an historical structure that accommodates his unique way of viewing history. These terms materialize from the basic notion that, for Castro, "historical life consists in an inner trajectory or process in which external motivations acquire form and reality; that is, they are converted into deeds and events that have a meaning."xii In other words, the intellectual, societal, and even geographical environment of an historical agent, or "subject-agent" in Castro's terms, determine the agent's existence. This existence is 
reflected in the agent's actions and productions. As deeds reflect the existential condition of the agent, the "inwardness" or "peculiar physiognomy of a people," they also define the historical form and reality of a people. ${ }^{\text {xiii }}$ Thus deeds carry meaning on several levels for Castro. On the one hand they determine the mode of life, what Castro terms the "dwelling place of life" (morada vital), which is the way an agent is perceived in its history as having existed on account of its actions. ${ }^{\text {xiv }}$ On the other hand deeds represent "living structure," or vividura. ${ }^{\mathrm{xv}}$ Living structure reflects the "mode according to which" the agent operates, the equivalent of that reflexive quality mentioned above in which environmental circumstances are revealed according to the agent's deeds. Morada vital and vividura are the dialectical essences that, for Castro, activate historical inquiry, enabling a critical process that reveals to the historian the actual existential condition of a people. Naturally Castro viewed this method as distancing the historian from the kind of deterministic biases that informed his predecessors, because the actual historical agent can be understood according to its own environmental circumstances, rather than the value-laden judgments of the historian themself.

Castro applies the dialectic of morada vital and vividura to the existential condition of the Iberian peoples in the Middle Ages. By examining the dialectic across the Peninsula's dominant religious groups, Christians, Muslims, and Jews, Castro determines that their cultural traditions suffused with one another significantly. This cultural interplay, what Castro terms "living togetherness," or convivencia, effectively amounted to a pluralistic Iberian society. For Castro the process of convivencia is an unrelenting, omnipresent dialectic between cultures. The process entails an interplay that is not limited to peacetime exchange. On the contrary, in many cases the interplay becomes most pronounced through deeds of violence, as is especially apparent in the emergence of the Hispanicized Christians of northwestern Iberia in the eighth and ninth centuries. 
It is in the eighth and ninth centuries that Castro demonstrates that the Christians living along the strip of territory along the Atlantic in northern Iberia, especially the most isolated Galicians in the Northwest, began to take on their peculiarly Spanish vividura. Cut off from their Visigothic roots, the Christians of northern Spain began to adapt to their new environmental circumstances, which entailed an abundance of interaction with the Muslims that had conquered Visigothic Spain in the early-eighth century. From these interactions Christians gleaned a "host of things-material and human-created by the Moors."xvi This process of convivencia eventually yielded medieval Spain, "the result of the combination of an attitude of submission and wonder in the face of a culturally superior enemy and of the effort to overcome this very position of inferiority."xvii As the passage suggests, Castro argued that the Spanish had acculturated both peaceful and militant practices from the Muslims, on account of which their vividura began to reflect their disposition in the form of cultural production.

Castro qualifies his philosophy of history via this theoretical framework of "living-togetherness," what is in itself determined by "the dwelling place of life" and "living structure." It makes perfect sense, then, that when Castro introduces Saint James into the mix, the Saint embodies the traits that it does, and subsequently represents such a watershed in the trajectory of Spanish history. Indeed, Castro refers to the saint as Spain's "axis," an entity that propels the dialectical process of Spain's self-fashioning through the later Middle Ages and into modernity. ${ }^{\text {xviii }}$ At the crux of Castro's idea of Saint James is the Saint's embodiment of a "theobiosis."xix Constituting belief in the Saint is an amalgamation of folkloric, pagan spiritual tradition, Christian creed, and Muslim influence. The Galician people's instigation of this theobiosis is a product of what had transpired in their "dwelling place," isolated by circumstance from the rest of Christendom, and solidified by their active opposition to the objective and extra-personal religious forms that made up Christianity 
in the broader European context of the ninth century. ${ }^{\mathrm{xx}}$ On one end of this theobiosis is a lingering pagan spirituality that campesinos had preserved in the relatively isolated frontier society of Visigothic Iberia, what was a vestige of the Peninsula's Roman days. On another end is the recent, and overwhelming colonial presence of the Muslims that rapidly brought on the desolation of the Visigothic political administration in the early-eighth century, and became thoroughly saturated in the Iberian "dwelling place" by the ninth. On yet another end of the theobiosis is the uniquely Galician form of Christianity, a personalized and indomitable belief that resulted from the precarious situation of a constant confrontation with Muslim expansion. ${ }^{x x i}$ Effectively it is a direct consequence of Galicia's structural circumstances, their "dwelling place," that Saint James, the expression of Galicia's "living structure," takes on the peculiar traits that he does.

Before further detail of Castro's Saint James is presented, it must be emphasized that these broader concepts composing Castro's representation of the Saint are directly related to his theoretical framework of history. Castro reminds his readers of the quality of his synthesis not as a manipulation of mere historical events, but as a consideration of the "vital points of view, the feelings of a people as they faced the world around them." ${ }^{x x i i}$ The unique qualities of the Spanish people came into their own through Christian Iberia's existential crisis, precipitated by the conditions of life in a frontier society, ridden with violence, and composed of various ethnoreligious groups interacting on both peaceful and militant terms. This existential condition, as Castro sees it, takes form via the dialectic between morada vital and vividura, both the essences that eventually determine Spain's peculiar habits and manners of existing. ${ }^{\text {xxiii }}$ And again, unique to Spain is the circumstance of convivencia, the umbrella term that encompasses all of these processes, and in the ninth century materializes in the theobiotic figure of Saint James.

Castro describes the pagan element of Saint James as constituting an important place in the rise to eminence of James' cult. While the 
belief that James was the son of Zebedee, a fisherman from Bethsaida, became orthodox by the thirteenth century, as the Castilian poet Gonzalo de Berceo's Poema de Fernán González illustrates, it was held in popular Galician tradition in the early Middle Ages that James was actually a brother of Jesus. ${ }^{\text {xxiv }}$ This belief came from: one, the legacy of the Dioscuri which had survived in Spanish folklore, and two, a misreading of the Gospel of Matthew, which addressed James as the brethren of the "carpenter's son" (Matt. 13:55). With respect to the latter conflation, Castro explains the verse was no doubt not meant to be taken literally, but it was because of the lingering essence of the former that theologians in Christian Iberia were so willing to extrapolate the message of the scripture to its status quo in Galicia in the early Middle Ages. ${ }^{\mathrm{xxv}}$ The Dioscuri were in Roman and Greek belief the twin sons of Jupiter, Castor and Pollux, militant equestrian gods frequently depicted in classical art as riding white horses into battle. Numerous parallels may be drawn between the two cults, such as the belief that one brother, Castor in the pagan tradition, "ascended to heaven while the other remained on earth (at least for some time) as a protector of man."xxvi To juxtapose James' relationship with Jesus in the popular belief of the early cult of Saint James shows clearly a similarity between the two traditions.

In Castro's view, the adamant belief among Spanish Christians that Saint James was a brother of Jesus was only able to reach such profundity because of the second element composing the Saint's theobiosis: the Muslim invasion. "If Spain had not been submerged by Islam," Castro says, "the cult of Santiago of Galicia would not have prospered."xxvii It is to say, if the Christians had not been conquered by the Muslims, they would not have learned how to conquer the Muslims in return. This dominance required the centralization of the belief of the Hispano-Christian people in an entity like Saint James, who is, to Castro, a "counter-Mohammed."xxviii As Mohammed had inspired the Islamic conquest of the Peninsula, Saint James served a similar role as inspiration for "reconquest."xxix Such a notion echoes 
the previous discussion of Castro's understanding of "dwelling place" and "living structure." The Saint, embodying classical tropes that had existed in the belief of the people for hundreds of years, syncretized with the Muslim tradition of a strong concentration of belief on a militant and prophetic figure in the form a uniquely Spanish Christianity: precociously militant and composed of various syncretic elements. This theobiosis, in Castro's view, made up the new "living structure" of Spanishness, and it would constitute Christian mores on the Peninsula throughout the Middle Ages.

Most crucial to Castro's idea of Saint James is its implications within his philosophy of history, because his treatment of the Saint entails more than simply identifying its syncretic elements. For Castro, the belief in Saint James is vitally connected to the Spanish essence. Again, he describes the nature of this essence on the basis of existential philosophy. "Out of the belief in Santiago grows a most original type of existence," explains Castro. ${ }^{\mathrm{xx}}$ The belief, a kind of $e x$ machina perspective of the Saint, comes to determine the way of life, the "living structure," of the Spanish people. ${ }^{\text {xxi }}$ This structure is the militant framework that constituted Spanish society in the Middle Ages. At the same time the belief in Saint James defines the "dwelling place" of Spanish existence. Deeds are expressed in cultural manifestations, which take the form of "works of anguished beauty (from Cervantes to Unamuno), in which life appears as it is, as a problem." "xxxii The same existential crisis Unamuno speaks of in the twentieth century, this "uncertainty" and "living in a state of alarm caused by doubt," permeates with the Spanish people's anxiety about their origins, their place within their multi-cultural structure of life. xxxiii Saint James thus is an expression of an irrational and instinctive process. This framework is the philosophy of history in which Castro views the cult of Saint James.

However much credence one can viably put in the empirical evidence Castro uses to back his argument, it is important to remember that his idea of history is not necessarily based on a system 
of "logical reason." ${ }^{x x x i v}$ He writes, "History, that is to say, the integral life of a peoples, is not a sequence of 'events,' isolable by means of logical abstractions."xxxv "History does not take place in a vacuum but in the life of a people." ${ }^{\text {xxxvi }}$ For understanding Spanish history, it is not whether the reader objectively agrees with the evidence of the faith in Saint James, the critical process of a rational inquirer. Rather, the understanding is hinged on grasping the existential reality of the Spanish people, one undeniably immersed in a kind of irrational and illogical belief. Castro describes this belief as a matter of life or death for the Spanish. "Peoples incapable of dying for a faith have never attained a complete reality," he says. ${ }^{\text {xxxvii }}$ This is the kind of belief the Muslims of Iberia clung to, and the kind the Christians learned to own as well. "We are such stuff as dreams are made of," quotes Castro, reminding his readers that the dream of a people, when "integrated into the total existence of millions," is a reality, and "reality is a dream." "xxxviii

Historians must understand that Castro operated within the context of a unique philosophy of history. His concepts, such as his idea of Saint James, are qualified within his own way of viewing history. This is because the theoretical elements composing his philosophy determine his representation of historical phenomena, just as it has been demonstrated with Castro's analysis of the rise of the cult of Saint James. In the end, the solution is to do one of two things. Either historians critique Castro within the context of his philosophy of history, or they cease to invoke him as an icon of previous distortions of historicity in the field. The twentieth century produced a range of scholars that have been categorized similarly to Don Américo. This group was not unique to Spain, not even to Europe, especially as colonial administrations produced contexts of oppression throughout the world similar to those of the Franco regime. All were intellectual obstructions, and for scholars such as Castro, all were mires that issued a higher calling for the expression of an oppressed people in existential terms, which, perhaps, allowed for the closest 
idea of reality attainable. The literature stemming from these circumstances deserves to be considered within its own context, on its own terms. Doing so will not only strengthen the revisionary scholarship that is to come; it will also work toward rooting out the hypocrisy of a Western age that claims to have realized the allinclusive democracy, but still refuses to understand its oppressive past on the terms of the literary expressions of its subjects.

In his 1960 text Saint James in Spain, T.D. Kendrick reminisced about the Spanish national holiday, El día de Santiago, describing the atmosphere of the festivities. "When the bells are ringing," writes Kendrick, "and the rockets are hissing and banging, and inside the cathedral the tapers are lit and the air is heavy with incense, then, when, with the gently hesitant dignity of the litter-borne image, Santiago, on his fine horse and with his flashing sword, moves in procession among his people, even the most incredulous of us might fittingly pay this blood-thirsty image a discreet act of homage. After all, Santiago Matamoros has worked wonders in Spanish hearts." Little would Kendrick have known that Castro would die twelve years later, "swimming in the Mediterranean Sea, in the little Catalonian resort town of Lloret de Mar," on the Día de Santiago, July 25, 1972. ${ }^{\mathrm{xl}}$ Rubia Barcia has already commented on the coincidental date of Castro's death. For a historian who emphasized so adamantly Saint James' role in determining the Spanish living experience, it only seems appropriate to have passed away in the midst of the essence of what El día de Santiago represented.

\section{Notes}

${ }^{i}$ Albert A. Sicroff, "Castro and His Critics: Eugenio Asensio," Hispanic Review 40, no. 1 (1972): 30, www.jstor.org/stable/471967.

ii Sicroff, "Castro and His Critics," 1.

iii Kenneth Baxter Wolf, "Convivencia in Medieval Spain: A Brief History of an Idea," Religion Compass 3, no. 1 (2009): 74, cf. Peter Linehan, History and the Historians of Medieval Spain (New York: Oxford, 1993), 15. 
iv José Rubia Barcia, "What's in a Name: Américo Castro (y Quesada)," in Américo Castro and the Meaning of Spanish Civilization, eds. José Rubia Barcia and Selma Margaretten (Berkeley: University of California Press, 1976), 18.

v Américo Castro, Santiago de España (Buenos Aires: Emecé Editores, 1958), 15 , my translation.

${ }^{v i}$ Américo Castro, The Structure of Spanish History, trans. Edmund L. King (Princeton: Princeton University Press, 1954), 5 n. 2.

vii Ibid., 24.

viii Ibid., 25.

ix Ibid.

${ }^{x}$ Ibid.

xi Ibid.

xii Ibid., 32.

xiii Ibid., 33.

xiv Ibid.

${ }^{x v}$ Ibid.

xvi Ibid., 82.

xvii Ibid., 83.

xviii Ibid., 79.

xix Ibid., 131.

xx Ibid., 127.

xxi Ibid., 126.

xxii Ibid., 127.

xxiii Ibid.

xxiv Ibid., 131.

xxv Ibid.

xxvi Ibid.

xxvii Ibid.

xxviii Ibid., 151.

xxix Ibid., 149.

xxx Ibid., 131.

xxxi Ibid., 183.

xxxii Ibid.

xxxiii Ibid., 25.

xxxiv Ibid., 5 n. 2.

xxxv Ibid., 147.

xxxvi Ibid., 157.

xxxvii Ibid., 147. 
Anthós, Vol. VI, Issue 1

xxxviii Ibid.

xxxix T.D. Kendrick, St. James in Spain (London: Methuen and Co. Ltd., 1960), 200.

${ }^{x l}$ Rubia Barcia, "What's in a Name," 20.

\section{Bibliography}

Barcia, José Rubia. "What's in a Name: Américo Castro (y Quesada)." In Américo Castro and the Meaning of Spanish Civilization, edited by José Rubia Barcia and Selma Margaretten, 3-22. Berkeley: University of California Press, 1976.

Castro, Américo. The Structure of Spanish History. Translated by Edmund L. King. Princeton: Princeton University Press, 1954.

—. Santiago de España. Buenos Aires: Emecé Editores, 1958.

Kendrick, T.D. St. James in Spain. London: Methuen, 1960.

Linehan, Peter. History and the Historians of Medieval Spain. New York: Oxford University Press, 1993.

Pi-Sunyer, Oriol. "The Historiography of Américo Castro: An Anthropological Interpretation." Bulletin of Hispanic Studies 49, no. 1 (1972): 40-50.

Sicroff, Albert A. "Castro and His Critics: Eugenio Asensio." Hispanic Review 40, no. 1 (1972): 1-30. www.jstor.org/stable/471967.

Wolf, Kenneth Baxter. "Convivencia in Medieval Spain: A Brief History of an Idea." Religion Compass 3, no. 1 (2009): 72-85. 